\title{
Ronald Ross to U N Brahmachari: Medical Research in Colonial India
}

\author{
John Mathew* \\ (Received 16 May 2018; revised 19 May 2018)
}

\begin{abstract}
The turn to the twentieth century would be accompanied by serious investigations into the nascent realm of germ theory. India was an important colonial crucible of experimentation, particularly given the magnitude of epidemic diseases that was encountered in several of its cities. Yet even as attempts were undertaken to elucidate the active causative agents, be they bacterial (e.g. cholera) or microparasitic (malaria), as well as their vectors, which caused such a panic of disease, with such notable instances as the plague in Bombay that began in 1896, the role of the colonial government in monitoring and controlling outbreaks would receive mixed reactions from the subject population. A significant fraction of the officiating doctors redounded to the Indian Medical Service, staffed predominantly by Europeans, including many who had cut their teeth in India itself, a significant example being Sir Ronald Ross, the Nobel prize-winning discoverer of the means whereby the malarial parasite is transmitted. Alongside, however, were some Indian practitioners trained in Western medicine, whose efforts would be incalculably important in stemming the relentless spread of disease. As the twentieth century grew, so would their numbers and influence, signalled by a Presidential address in 1936 at the $23^{\text {rd }}$ session of the Indian Science Congress by one of their most distinguished members, Sir Upendranath Brahmachari, whose discovery of Urea Stibamine would save Indian lives in the thousands from the parasitic disease kala-azar.
\end{abstract}

Key words: Bacteriology, Germ theory, Indian Medical Service, Kala-azar, Malaria, Parasitology, Plague.

\section{INTRODUCTION}

The intersection of Britons with India in the role of colonists was necessarily attended by considerations of health. From the seventeenth century itself, hospitals had been established in the colonies within close range of trading and military posts (Chakrabarti, 2010, p. 3). The Bengal Medical Service was created in 1763 with an initial complement of 40 surgeons. This model would be replicated in Madras and Bombay, leading in 1785 to a decision by the Court of Directors of the East India Company to set the number of surgeons and assistant surgeons for the three presidencies at 234 , a number that would rise to 630 by 1824 (Crawford, 1914, pp. 197-221). The eventual result was the formation of the Indian Medical Service (IMS), which met the needs of both civilians and armed services, such that doctors associated with the Service were also military men.

It was axiomatic that the IMS would be staffed in the main by Britons, whether sent from the United Kingdom, or as products of British parents based in India. Sir Ronald Ross (18571932) was an example of the latter. Born in Almora, a hill station in North India, the son of an English General Sir C C G Ross, he was sent to England to study, where he read medicine at St.

\footnotetext{
* Programme in the Humanities and Social Sciences, Indian Institute of Science Education and Research (IISER), Dr Homi Bhabha Road, Pashan, Pune 411008, Email: john.mathew@iiserpune.ac.in
} 
Bartholomew's Hospital in London, subsequent to which he joined the IMS in 1881. The key decade in his experimental life, however, was the $1890 \mathrm{~s}$, where, through a series of postings in southern and western India, and in consultation with Sir Patrick Manson (1844-1922), a pioneer in the field of tropical medicine with years of experience in China, and the founder of the London School of Hygiene and Tropical Medicine, as well as following the hypothesis of the French identifier of the malarial parasite Alphonse Laveran (1845-1922) - that the parasite should exist outside the human host, Ross was able to determine that the vector for malaria was indeed the mosquito, a discovery that would garner for him the Nobel Prize in Physiology [Nobel Lectures (1967), Ross, Biographical]. Ross's own sense of elation upon apprehending what he had done was captured in a poem that he wrote to his wife, the words of which are inscribed upon the outer wall of the P G Hospital in Calcutta (Fig. 1), less than a hundred yards from the site of his seminal finding (Fig. 2).

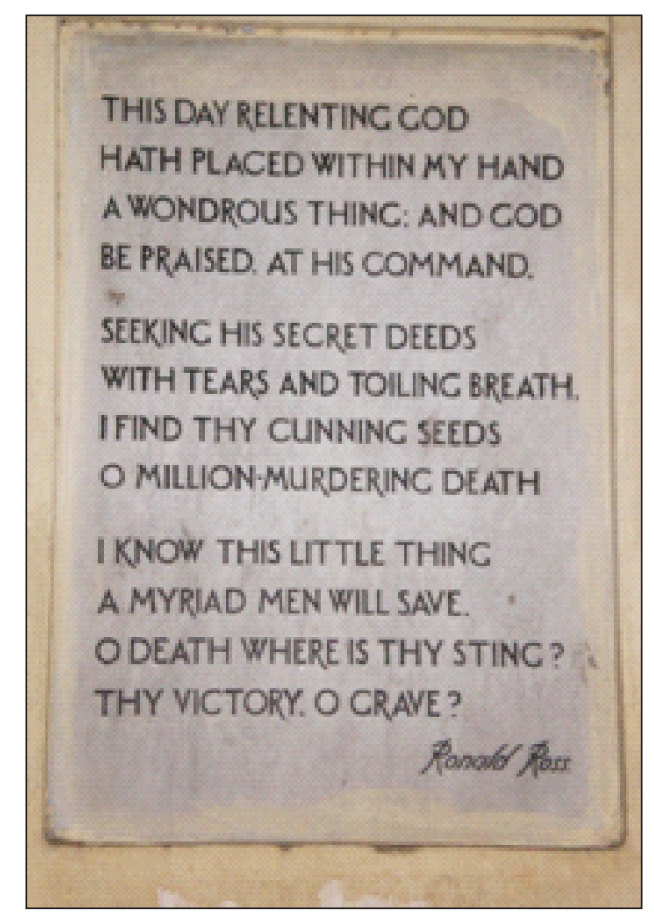

Fig. 1. Ross's Poem in the Tablet of P G Hospital, Calcutta (Photograph by the author)

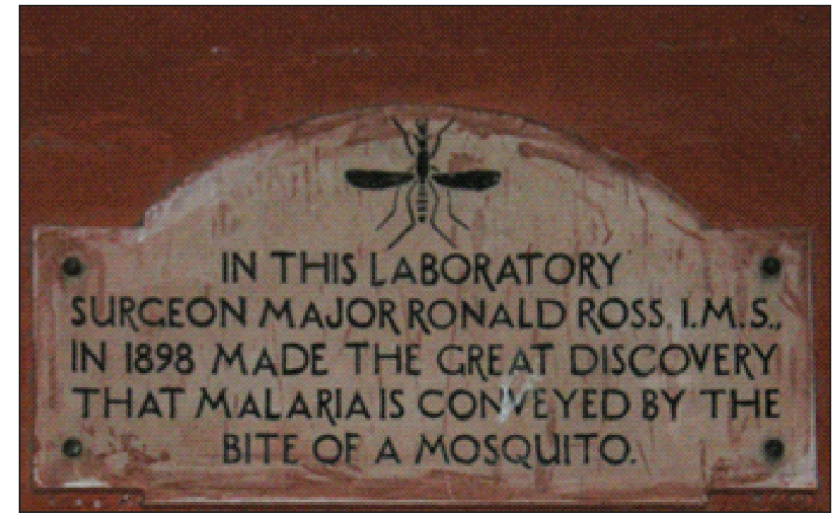

Fig. 2. Epigraph in the P G Hospital, Calcutta pointing to the discovery by Ross for the cause of Malaria in 1898 (Photograph by the author)

Yet Ross was not quite so sanguine about medical facilities in India in general. They were apparently organised in so poor a fashion that major locations lacked libraries. At the same time, very little attention was paid to the systematic investigation of particular diseases, despite the presence of competent clinicians, and if anything, advances in bacteriology spearheaded by Robert Koch and Louis Pasteur were but dimly regarded (Arnold, 2000, p. 141). Ross himself had been routinely stymied by the medical bureaucracy in India with respect to the prosecution of his work on malaria during the early 1890 s. It would take the near contemporaneous discovery of the causes and the means of communication of both malaria and the plague to energise both laboratory-based science and field research, the latter which comprised 'medical entomology, helminthology, malaria surveys, and the investigation of the lifecycles and habitats of fleas, mosquitoes and other insect vectors' (Arnold, 2000, p. 144).

The outbreak of the plague in India would change the landscape of societal response to disease. The Third Pandemic had found its origins in Hong Kong and southern China in 1894 and two years later struck Bombay and its environs with tremendous ferocity. Over the next fifty years, even as the intensity of the disease waxed and waned, there were up to 15 million deaths 
worldwide, of which approximately 12 million were in India alone (Echenberg, 2002, pp. 42949). The colonial government was slow to respond, even as state intervention reigned, rumours abounded, riots resulted, and mass flight occurred from cities (Arnold, 2015, p. 112). A major element in the draconian measures adopted by the colonial government was the fact that an international sanitary meeting held in Venice in 1897 threatened to impose an embargo on goods imported from India (Arnold, 1993, p. 205). A countervailing measure in place in India was the promulgation of the Epidemic Diseases Act in February 1897, which 'authorised the health authorities to confiscate or destroy any property including houses) that they believed to harbour the disease; gave them the right to prohibit fairs and festivals where these might endanger public health; permitted the hospitalisation and segregation of suspected plague victims; allowed the rapid disposal of the dead to prevent the spread of disease; and instituted systematic inspection of travellers by road, rail, and sea to search for physical signs of infection and detain plague suspects' (Arnold, 2015, p. 114). What might now be recognised as a Foucauldian sense of disciplining clearly invested the government, with its resident fears made manifest through repression. The result was widespread fear amongst both the western educated Indian elite and the less fortunate masses, with rumour running riot, and responses occasionally assuming the trappings of the violent against this apparent manifestation of the White Man's burden. Only two years earlier, the unpopular Plague Commissioner in Poona, Walter C Rand, along with a Lieutenant Ayerst, who had the misfortune of being in his company at the time and consequently suffering the same fate, had been assassinated on the $22^{\text {nd }}$ of June 1897, the occasion of the Diamond Jubilee of the accession of Queen Victoria to the throne of Great Britain at the hand of three Chitpavan Brahmins, the Chapekar brothers (Ratna, 2010, pp. 230-231).

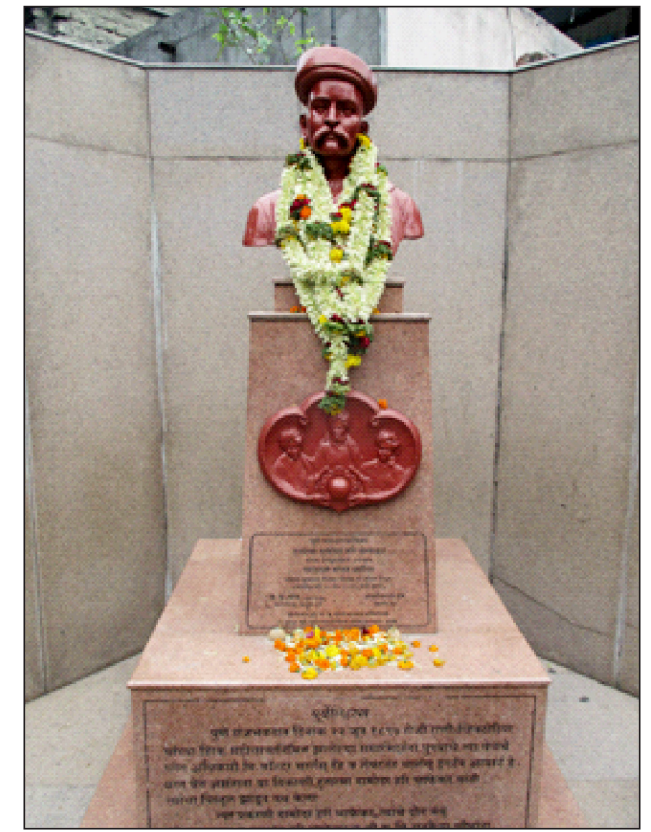

Fig. 3. The Chapekar Memorial, Ganeshkhind Road, Poona (Photograph by the author)

Bombay had, earlier the same year seen nearly 400, 000 people, approximately half the population, flee the city (Arnold, 2015, pp. 11617). Some measure of addressing immediate discontent was to be found in the anti-plague serum developed by Waldemar Haffkine (18601930), a Jewish Ukrainian bacteriologist trained in Paris, who had, half a decade earlier, helped address a cholera outbreak in Calcutta. Less successful was a serum concocted in Indo-China (present day Vietnam) by the co-discoverer [with the Japanese bacteriologist Shibasaburo Kitasato (1853-1931)] of the plague bacterium in Hong Kong, Alexandre Yersin (1863-1943), after which it is now named (Yersinia pestis), whose visit in 1897 proved to be a failure, (Deville, 2012, pp. 127-134), his stock of vaccines being too attenuated to be of use. Haffkine's serum itself would, through a moment of contamination that was not of his doing, compromise his work and standing in the country. Nonetheless, the plague pandemic had allowed for the systematic employment of a laboratory-derived antidote from within the confines of a nation hitherto under thrall 
to more environmental considerations in the treatment of disease, rather than those of pathogens.

\section{Points of Departure}

There are three major points of departure that I foreground from the plague epidemic. The first deals with the index case of the disease in Bombay, which was detected by an Indian physician, A G Viegas (1856-1933). He becomes symbolic of a larger swath of native practitioners in western medicine that will form part of this narrative, concluding with Sir U N Brahmachari. The second is the reaction of the city to an even more deadly epidemic, the Great Influenza of 1918-19, which was quite at odds with that encountered in the first flush of the plague. The third is the development of tropical medicine itself with considerable links to the establishment of Pasteur institutes and medical schools devoted to the subject in India.

\subsection{Native Practitioners}

When Dr A G Viegas became the first person to detect a case of the plague in Bombay, he was a member of the Bombay municipal standing committee, under whose remit the responsibility of controlling the disease fell (Ramanna, 2012, p. 11). Viegas was a local physician, of Goan extraction, with a thriving practice in Mandvi, whose suspicions regarding the rebarbative symptoms of a woman on whom he had been called to attend in Pydhonie on the $18^{\text {th }}$ of September 1896, had led to his determination of her illness as the plague. This fact was duly confirmed on the $23^{\text {rd }}$ of September by a Standing Committee, leading to the then Governor of Bombay, Lord Sandhurst, notifying the Governor-General and Viceroy of India, Lord Elgin on the $29^{\text {th }}$ of September, that the plague had broken out in Bombay (Ratna, 2015, pp. 2425). Viegas, despite his local reputation, was, however, not an IMS man.
This fact was not surprising. After all, the separation between European and Indian practitioners had been carefully maintained. If in the $18^{\text {th }}$ century, there were 'native dressers' (Madras), 'country doctors' or 'black doctors' (Bengal), or 'black assistants' and 'apothecaries' (Bombay), (Buchanan, 1914, p. 436), the early $19^{\text {th }}$ century witnessed a greater level of organisational ordering into what was known as the Subordinate Military Medical Service. However, as the $19^{\text {th }}$ century advanced, Indian practitioners of western medicine found that the highest to which they could aspire in the colonial service was what was called the Uncovenanted Medical Service. It would eventually take a remarkable Bengali, Soorjo Coomar Goodeve Chuckerbutty (c.18261874), whose studies were sponsored through a combination of government support and private enterprise, to read for a medical degree at University College, London, gaining the MRCS in 1848 and the MD in 1849, before returning to India as a member of the Uncovenanted Service. Subsequently he sat successfully for the examination of the Covenanted Medical Examination in 1855, administered only in England at the time (Crawford, 1914, p. 442). Despite his return to India to assume the chair of Materia Medica at the Calcutta Medical College, the numbers of his successors to the IMS remained modest, a fact that would begin to change only after the turn to the twentieth century.

It is against this backdrop that the work of Viegas, and other native practitioners of western medicine who did not belong to the IMS, becomes important, so also Indian supporters such as the Aga Khan, whose supporters were in charge of an inoculation station from March to December 1897 (Ramanna, 2011, p. 567). One particularly influential figure was Khan Bahadur Dr Sir Nusserwanji Choksy (1861-1939), the physician in charge of the Arthur Road Hospital and the Mahratta Hospital, who through four epidemic outbreaks of the plague would garner the largest 
clinical experience of the plague in Bombay, with over 4000 cases (Ratna, 2015, p. 153). As assistant health officer in charge of the plague operations, he conducted experiments using eight different vaccines developed by Yersin and Roux, Haffkine and Lustig, as well as others by Terni, Tavel, Palthauf, Brazil and Kitasato, with regular reports sent to the Lancet and the British Medical Journal. These studies represented 'an important yet little known instance of bacteriological investigations in India, both for its international implications as well as for local factors' (Chakrabarti, 2012, p. 53).

\subsection{The Great Influenza (1918-1919)}

Easily the most cataclysmic epidemic that has struck India at any one point in terms of daily mortality, the Great Influenza of 1918-19 has received disproportionately little attention in historical accounts within the country. The figures are largely discrepant, with a global range of anywhere between 30 and 100 million. In a recent paper comparing the 1896 plague and the 1918 influenza, David Arnold points to the fact that '[a]ccording to official statistics, influenza resulted in 12.5 million deaths in India, a figure that has subsequently been revised upwards to 18 or even 20 million'(Arnold, 2015, pp. 111-112). My own research in the Maharashtra State Archives shows from a letter to the Commissioner from the Collector of Sholapur, dated the $26^{\text {th }}$ of September, 1918 , that the death rate, typically about 10 per day, rose to 180 on the $25^{\text {th }}$. While total figures remain inexact, the fact remains that the country witnessed between a third and a half the number of all global mortalities.

This is why Arnold's paper (2015) assumes particular significance. The key question that he asks is along this wise:

[W]here plague provoked full-scale panic.....the greater and more temporally concentrated mortality of the influenza epidemic gave rise to abundant rumour but otherwise passed without any major panic or upheaval...So why, in terms of panicked reactions, was the influenza epidemic, to quote Sherlock Holmes, the "dog that didn't bark? (Arnold, 2015, p. 111).

Arnold advances a number of reasons. The first was the experience of addressing the plague in a manner that had been so unpopular by the colonial government that on a new epidemic visitation, there was far less intervention by the state. Second, the First World War had exacted its toll on the medical and sanitary services in India, not least senior medical functionaries. Third, the fact that the disease had made its way from the West to the East queered the pitch - given Europe's impotence in dealing with the disease, not much could be expected from India on this count. Fourth, the relative absence of a state policy enabled local leaders of communities to take charge of resources and intervene directly. Fifth, the likely promulgation of the reviled Rowlatt Bills, (which indeed did make it into an eponymous Act), was a leading preoccupation of nationalist leaders, not least Gandhi himself. An additional angle was the sheer weariness resulting from the scale and speed of the epidemic; the apathetic general response was likely in direct proportion to how overwhelming the losses were, such that comprehension of such staggering losses could be nothing but clouded in the coping. The fact that there was no recurrence in 1920 saw general interest wane further (Arnold, 2015, pp. 121-125).

To all of these thoughtful points needs to be added the development of studies in tropical medicine in India from the onset of the plague onwards. Arnold has not overlooked the matter but draws attention to the fact that given the bitter feelings towards plague inoculation in the past, an anti-influenza vaccine was not a popular consideration, even being deemed impracticable (Arnold, 2015, pp. 123, 125). That the disease itself was of viral origin would be elucidated only in in 1931 by Richard Shope in swine, and demonstrated similarly by $\mathrm{C} \mathrm{H}$ Andrewes, Patrick Laidlaw and Wilson Smith in 1933, chiefly pursuing Shope's methods (Barry, 2009, p. 446). 
The response on the part of the 'microbe hunters' in India (to use Paul de Kruif's famous term) in near retrospect was to look for a bacterial source. In 1922, a significant article appeared on just this topic by Mervyn Gordon in the British Medical Journal, whose abstract read as follows:

\begin{abstract}
The pandemic of influenza during 1918-19 served to bring home very forcibly the importance of microbiological knowledge, for there is good reason to believe that the severe defeat then suffered by preventive medicine was due in great part to our ignorance with regard to the primary infective agent of this disease. In these circumstances it is clearly the duty of bacteriologists to make all possible use of opportunities that may occur of investigating cases of influenza, and to submit their observations for discussion and criticism at meetings such as the present one (Gordon, 1922, pp. 299-306).
\end{abstract}

The context was clear - a clarion call for tropical medicine to come of age.

\subsection{Tropical medicine}

When Gordon read his paper (quoted above), Sir William Boog Leishman (1865-1926) was in the chair. His presence was not adventitious. A distinguished Director of the Army Medical Services from 1923 to 1926 , he had entered that department in 1887 , and was posted in 1890 to India, where he spent seven years studying tropical diseases, in particular, kala-azar and enteric fever, before being reassigned to Netley Hospital in England, where he discovered the parasite that causes kala-azar, a signal achievement that would lead Ronald Ross to place the causative agent under the generic name Leishmania. Crucially, Ross saw a continuum for the study of tropical medicine as starting with parasitology rather than bacteriology, when, in the late nineteenth century, the words germs and parasites were used interchangeably in relation to Pasteur's or Koch's work (Chakrabarti, 2012, p. 9). Part of the issue with the British standing at some point of remove from bacteriology was that it was largely seen as the preserve of continental Europeans, in particular, the French and the Germans. However, what was largely denied in Britain became permissible in British India at the turn to the twentieth century, the formation of Pasteur Institutes in various places across the country, from Coonoor to Kasauli, Calcutta to Rangoon. These, along with establishments of government, be it the short lived Imperial Bacteriological Laboratory in Poona, later shifted to Muktesar (1890) or the still existent Calcutta School of Tropical Medicine (1921), pointed to colonial crucibles of experimentation, where case studies aplenty presented themselves with such outbreaks as the plague or the Great Influenza. In the years between 1900 and 1914, the Government instituted a number of agencies that would dominate Indian medical research for decades, such as the King Institute in Madras (1904) and the Central Research Institute in Kasauli (1906), the same year in which the Bacteriological Department (later known as the Medical Research Department) came into being. In 1911, the Indian Research Fund Association (IRFA) was established for the recruitment and training of medical researchers as well as a conduit for funding both from the government and from private philanthropists. From 1913 its research appeared in the Indian Journal of Medical Research, which itself came to be widely regarded for the publication of pioneering research on cholera, hookworm, kalaazar, malaria and the plague. In the meantime, work proceeded at the Plague Research Laboratory in Bombay (1899), renamed the Haffkine Institute in 1925. With concerted state support, research soared. W G Liston (1872-1950) made rapid strides on the study of plague in Bombay as did S R Christophers (1873-1978) on malaria in Kasauli. The Calcutta School of Tropical Medicine was given a decided fillip through the endeavours of Sir Leonard Rogers (1868-1962). All these efforts would go a long way towards reversing the situation in the 1890s that Ross so deplored, such that by the 1920, India's reputation in the field of medical research would obtain a significant 
facelift, and come to hold its own globally in the treatment of tropical diseases (Arnold, 2000, pp. $144-145)$.

An important development in the 1910s was the formation of the Indian Science Congress in January 1914 at the behest of the chemists Professor P S MacMahon of Canning College, Lucknow, and Professor J L Simonsen of Presidency College, Madras. Medicine would soon make its presence felt through a series of Presidential addresses by key workers in the field, some of whom are mentioned above. In 1915, W B Bannermann gave the second, in Madras on the topic The Importance of a Knowledge of Biology to Medical, Sanitary and Scientific Men Working in the Tropics, where the role of vectors and intermediate hosts was discussed (a significant connection between zoology and disease). The sixth, in 1919 in Bombay, was delivered by Sir Leonard Rogers, Researches on Cholera, while S R Christophers accounted for the seventeenth, The Science of Disease, at Allahabad in 1930. It was, however, with the twenty third, in Indore that an Indian spoke in the capacity of President on the subject, The Role of Science in the Recent Progress of Medicine. His name was Sir Upendranath Brahmachari (1873-1946).

Born in Jamalpore in what is now Bihar in 1873, Brahmachari (with whom this account ends) studied medicine (like his father), and surgery. He joined the Provincial Medical Service in 1899, and in 1902, obtained both an MD and $\mathrm{PhD}$ in physiology from Calcutta University. After a brief sojourn in Dacca, he began a long stint in 1905 at the Campbell Medical College, Calcutta. Whilst there, he embarked upon an attempted cure for kala-azar, first with antimony, in 1916, and in 1922, with Urea Stibamine (synthesized from urea and stibanilic acid), which was swiftly used in Assam, where an epidemic had been raging. The cure was miraculous, a drop from 12 weeks to a fortnight. Major Shortt and Dr Sen from the Pasteur Institute, Shillong, reported to the Indian kala-azar Commission that Urea stibamine was the most efficient drug for the treatment of the disease (Ranganathan and Ranganathan, 2017). As Brahmachari himself stated in his Presidential address:

Early in 1921, the speaker discovered an urea antimony compound for the treatment of KalaAzar. Its introduction and his other researches on antimonial compounds opened up a new vista in the treatment of the disease in India by means of therapeutic organic antimonials, just as the discovery of salvarsan led to the introduction of organic arsenicals in the treatment of spirochaetal diseases. This urea compound was named Urea Stibamine (Brahmachari, 1935, p. 371).

This characteristically modest description of the synthesis of Urea Stibamine does not reveal the fact that thousands of lives would be saved as a consequence of its dissemination.

Clouds would sadly occlude the continuing ascent of Brahmachari's star. Rajinder Singh has expatiated on the controversy of his being denied a Fellowship of the Royal Society, despite support from such luminaries as Meghnad Saha (1893-1956) and for a while J L Simonsen (who later withdrew). It was Sir Leonard Rogers who was dismissive of the results, and his intervention was such as to delay election. Ultimately, Brahmachari would die without becoming a Fellow (Singh, 2014, pp. 29-37). In 1929, he was also unsuccessfully nominated for a Nobel Prize in Physiology and Medicine.

Mixed recognition notwithstanding, Brahmachari was a blazing light in the firmament of Indian medical research. He may have furthered the work begun by European workers like Ross and Leishman, but his indefatigable spirit would keep the flame kindled as an inspiration for his compatriots, even as the torch of medical research was inexorably passed from Briton to Indian.

\section{BibliograPHY}

Arnold, David. Colonising the Body: State Medicine and Epidemic Disease in Nineteenth-Century India, 
University of California Press, Berkeley/Los Angeles/ London, 1993.

Arnold, David. The New Cambridge History of India: III. 5. Science, Technology and Medicine in Colonial India, Cambridge University Press, Cambridge, 2000.

Arnold, David. Disease, Rumour, and Panic in India's Plague and Influenza Epidemics, 1896-1919 in Robert Peckham (ed.), Empires of Panic: Epidemics and Colonial Anxieties, Hong Kong University Press, Hong Kong, 2015, pp. 111-129.

Barry, John. The Great Influenza: The Story of the Deadliest Pandemic in History, Penguin, New York, 2009.

Brahmachari, U N. $23^{\text {rd }}$ Presidential Address, 1936, Indore. The Role of Science in the Recent Progress of Medicine in The Shaping of Indian Science, Indian Science Congress Association Presidential Addresses, Vol. I. 1914-1947, Universities Press, Hyderabad, 2003, pp. 355-393.

Buchanan, W J. The Introduction and Spread of Western Medical Science in India, Calcutta Review 1.278 (1914): 436, cited in Anil Kumar, Medicine and the Raj: British Medical Policy in India 1835-1911, Thousand Oaks, New Delhi, 1998, p. 18.

Chakrabarti, Pratik. Materials and Medicine: Trade, Conquest and Therapeutics in the Eighteenth Century, Manchester University Press, Manchester and New York, 2010.

Chakrabarti, Pratik. Bacteriology in British India: Laboratory Medicine and the Tropics, University of Rochester Press, Rochester, New York, 2012.

Crawford, D. G. A History of the Indian Medical Service 1600-1913, Volume II, W Thacker \& Co., London, 1914.
Deville, Patrick. Peste \& Choléra, Fiction \& Cie, Édition du Seuil, Paris, 2012.

Echenberg, Myron. Pestis Redux: The Initial Years of the Third Bubonic Plague Pandemic, 1894 - 1901, Journal of World History, 5.2 (2002): 429-49.

Gordon, Mervyn. Discussion on the Bacteriology of Influenza, The British Medical Journal, 2 (3216) (1922), pp. 299-306.

Nobel Lectures, Physiology or Medicine 1901-1921, Elsevier Publishing Company, Amsterdam, 1967 https://www.nobelprize.org/nobel_prizes/medicine/ laureates/1902/ross-bio.html.

Ramanna, Mridula. The Haffkine Institute, 1899-1947 in Uma Das Gupta (ed.) Science and Modern India: An Institutional History, c. 1784-1947, Vol. XV, Part 4, History of Science, Philosophy and Culture in Indian Civilisation, D P Chattopadhyaya (gen. ed.), pp. 563590.

Ramanna, Mridula. Health Care in Bombay Presidency, 1896-1930, Primus Books, New Delhi, 2012.

Ranganathan, Anand and Sheetal, Ranganathan. Brahmachari: The Forgotten Saint of Calcutta, Swarajya (Aug 19 $9^{\text {th }}, 2017$ ) https://swarajyamag.com/ science/brahmachari-the-forgotten-saint-of-calcutta.

Ratna, Kalpish. The Quarantine Papers, Harper Collins, New Delhi, 2010.

Ratna, Kalpish. Room 000: Narratives of the Bombay Plague, Macmillan, New Delhi, 2015.

Singh, Rajinder. Sir Upendranath Brahmachari and the Fellowship of the Royal Society of London, Science and Culture 80 (2014): 29-37. 